\section{Marker Cells}

in Tracheobronchial Mucus During Anti-Obstructive Therapy of Horses with Pulmonary Diseases

\author{
P. Costa and E. Deegen \\ Klinik für Pferde, Tierärztliche Hochschule Hannover
}

The main target of symptomatic and anti-obstructive therapy of horses with chronic respiratory diseases is not to reduce coughing but to open up the airways, especially the small ones. There are many ways to perform this which include:

1. bronchospasmolytic therapy,

2. reducing the edema of the mucosa and

3. expelling sputum from the airways with expectorant therapy.

There is no longer any doubt that these three pathomechanisms, namely bronchospasm, dyscrinea or hypercrinea and changes in the bronchial mucosa are, indeed, responsible for bronchial obstruction (Cook and Rossdale, 1963; McPhearson and Lareson, 1974; Schoon and Deegen, 1983).

The mechanisms causing obstruction will not be discussed in detail here, but airway hyperreactivity is probably a very important factor (Klein, 1984; Derksen et al., 1985).

If bronchodilator and expectorant therapy are to succeed, cytological examination should show an increase in the following structures in the tracheobronchial mucus:

1. those structures which caused the obstruction of the small airway or

2. those which were localized beyond the obstruction, namely in the alveoli.

Deconto (1983) performed cytological examinations of the mucus and found some structures that suggest bronchial obstruction:

1. Curschmann's spirals,

2. foamy macrophages and

3. giant cells.

About 100 years ago, Curschmann found some spiral structures in sputum from asthmatics. Tscherniak (1928) found similar structures in the small airways of horses. Many authors in the fields of human and veterinary medicine now agree that Curschmann's spirals are not characteristic of any disease but merely indicate obstructive bronchial disease of the small airways. According to Deconto (1983), Curschmann's spirals are thickenings of mucus, shaped to fit the lumen of small airways, which have been twisted because of the typical movement of the cilia in the mucosa on the way out of the lung.

Deconto (1983) also reports of an increase in foamy macrophages in the proximal tracheobronchial mucus after anti-obstructive therapy. Cohen and Cline (1972) and Kissler (1980) designated macrophages as foamy when their cyto- plasm was full of numerous vacuoles containing phospholipids which were presumably produced by type II cells.

In human beings there is an increase in type II cells and an increase in production of immature surfactant in alveoli under the influence of hypoventilation. This material is phagocytized by alveolar macrophages. Kaup et al. (1985) found the same process in horses.

Foamy macrophages in proximal tracheobronchial mucus indicate an obstruction in the small airways. This obstruction causes inadequate ventilation in alveoli.

Giant cells in tracheobronchial mucus indicate a deficient clearance in small airways. Probably because of turbulent airflow, large particles in air reach the alveoli. There they cannot be phagocytized by just a single alveolar macrophage but only by a giant cell.

The purpose of this experiment was to determine if there was any increase in "marker cells" such as Curschmann's spirals, foamy macrophages and giant cells in tracheobronchial mucus during bronchodilator and mucolytic therapy.

\section{Material and Methods}

Sixteen horses were medicated first with the bronchodilator clenbuterol (Ventipulmin ${ }^{\circledR}$ ) (phase A) and finally, with clenbuterol combined with a massive infusion of 0.9 percent saline solution (phase B).

Phase $A$

Clenbuterol was injected twice a day i.v. at a dosage of $0.8 \mu \mathrm{g} / \mathrm{kg} \mathrm{BW}$ for 8 days.

Phase $B$

At the end of phase A, the same horses continued receiving clenbuterol injections and also received an additional $30 \mathrm{l}$ saline solution i.v. daily for three days. The infusion was given with a catheter having an inside diameter of $1.7 \mathrm{~mm}$ placed into the external jugular vein and on average the infusion took 110 minutes. The infusion was performed under close supervision. All horses received a total infusion of 901 within three days. In the following four weeks they continued receiving clenbuterol at the same dose but orally rather than i.v. and the horses were also exercised.

Tracheobronchial mucus was collected by a flexible endoscope as described by Fischer (1980). The mucus specimens

CALIBRATED MICROSCOPIC SLIDE

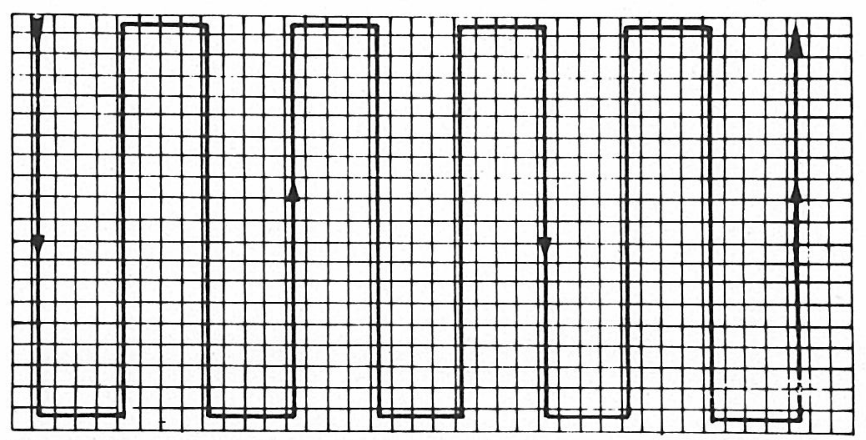

Fig. 1: Specially calibrated microscopic slide with a schematic demonstration of the search techniques (size $=2 \times 1 \mathrm{~cm}$ ). 
Table 1: Statistical comparison (analysis of variance) of phase $A$ and phase B concerning the number of Curschmann's spirals, foamy macrophages and giant cells during bronchodilator therapy and massive saline infusion with F-value and significance level.

\begin{tabular}{|c|c|c|c|c|c|c|}
\hline \multirow{2}{*}{ Varlable } & \multicolumn{2}{|c|}{ Phase A $+B$} & \multicolumn{2}{|c|}{ Duy of examination } & \multicolumn{2}{l|}{ Correlation } \\
\cline { 2 - 6 } & F-value & $\begin{array}{c}\text { Signif } 1 C \\
\text { level }\end{array}$ & F-value & $\begin{array}{l}\text { Signific. } \\
\text { level }\end{array}$ & F-value & $\begin{array}{c}\text { Signif. } \\
\text { level }\end{array}$ \\
\hline CS & 10.34 & $\bullet$ & 63.26 & $\bullet \bullet$ & $\mathbf{8 . 1 4}$ & $\bullet \bullet$ \\
FM & 4.80 & $\bullet$ & 52.20 & $\bullet \bullet$ & 16.20 & $\bullet$ \\
GC & 9.41 & $\bullet$ & 29.13 & $\bullet \bullet$ & 17.20 & $\bullet \bullet$ \\
\hline
\end{tabular}

$$
\begin{array}{rlrl}
\bullet & =\text { low significant } & \text { CS }=\text { Curschmann spirals } \\
\bullet-\text { significant } & \text { FM }=\text { Foany macrophages } \\
\bullet \bullet-\text { high significant } & \text { GC }=\text { Giant cells }
\end{array}
$$

were streaked on special glass slides called "Raster-slide". Staining of the slides was done by the Pappenheim procedure.

The search procedure is shown in Figure 1. Each of the three marker structures seen in the field of view was counted. Trachebronchial mucus was collected and examined before beginning therapy, every day during therapy after the daily dose and at the end of therapy.

In phase B (massive infusion) the mucus was always collected two hours after the end of saline infusion. The results were statistically analyzed by a two factorial analysis of variance.

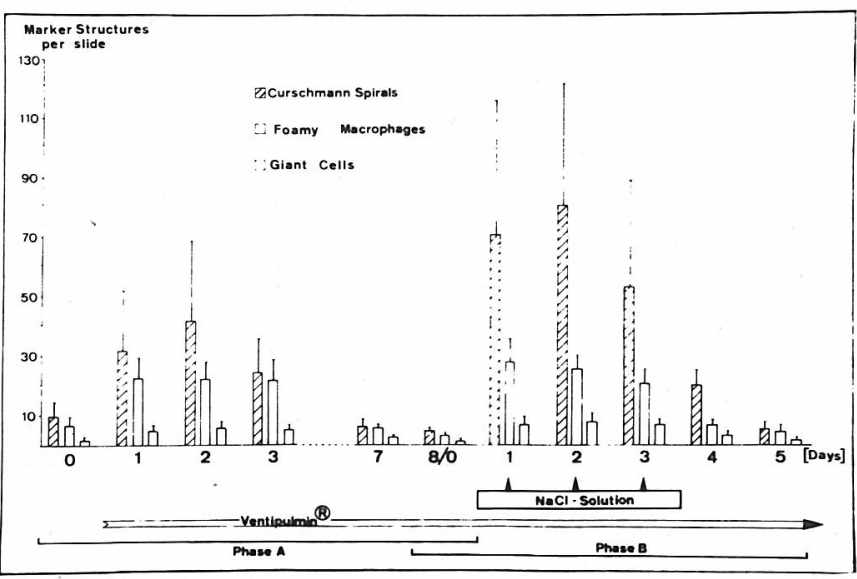

Fig. 2: Average and standard deviation of Curschmann's spirals, foamy macrophages and giant cells in sputum before, while and after therapy with clenbuterol (phase A) and after combining clenbuterol therapy with massive infusion of saline solution (phase B).

\section{References}

Coben, A.B., and Cline, M.J. (1972): In vitro studies of the foamy macrophage of postobstructive endogenous lipoid pneumonia. Am. Rev. Respir. Dis. 106, 69-78.

Cook, W.R., and Rossdale, P.D. (1963): The syndrome of "Brocken Wind" in the horse. Proc. R. Soc. Med. 56, 972-977.

Deconto, I. (1983): Zytologische und bakteriologische Untersuchungen des Tracheobronchialsekretes bei chronisch lungenkranken Pferden. Hannover, Tierärztl. Hochsch., Diss.

\section{Results}

Both therapies (phase A and phase B) were associated with a highly significant increase of the three structures in the mucus (Table 1 and Figure 2).

During the initial clenbuterol therapy there was an increase of these three structures on the 1st, 2 nd, and $3 \mathrm{rd}$ day. On the 7 th and 8 th day the values were nearly the same as those found before therapy. Immediately after initiation of phase B (massive infusion) there was a highly significant increase of these structures. On the 5th day after starting phase $\mathrm{B}$ the values were nearly the same as before the therapy.

Comparison of both phases, A and B, was statistically highly significant. In phase $B$ there was a higher increase of these structures than in phase A.

\section{Discussion}

Drastic increases in Curschmann's spirals, foamy macrophages, and giant cells during anti-obstructive therapy confirm the following hypothesis: an increase in these structures in proximal tracheobronchial mucus shows the efficacy of expectorant therapy, especially in the small airways. Both therapies showed significant differences in expectorant effect which means that determination of secretion cytology allows evaluation of the cleaning effect in the small airways of different anti-obstructive therapies.

The association of bronchodilator therapy and massive infusion of saline solution (phase B) removes Curschmann's spirals, foamy macrophages and giant cells better than bronchodilator therapy alone (phase A). Bronchodilator therapy alone provokes an increase in these structures on the first three days, while on the 7 th and 8 th day the values are approximately the same as before the therapy. These results suggest that this therapy probably removes secretions which are not so strongly trapped in the bronchial lumen. Clinical experience shows that thorough cleaning of the small airways by bronchodilator therapy needs a long time to succeed in many patients (Deegen, 1985).

The above mentioned combination therapy shows that, in spite of the initial increase of marker cells in the mucus after bronchodilator therapy an even better cleaning effect was seen after the bronchodilator therapy was combined with saline infusion intravenously.
Deegen, E. (1985): Personal communication.

Derksen, F.J., Robinson, N.E., Amstrong, P.J., Strick, J.A., and Slocombe, R. F. (1985): Airway reactivity in ponies with recurrent airway obstruction (Heaves). J. Appl. Physiol. 58, 598-604.

Fischer, J. (1980): Bronchoskopische Untersuchungen als Beitrag zur klinischen und ätiologischen Diagnostik bei Pferden mit Atemwegserkrankungen. Hannover, Tierärztl. Hochsch., Diss.

Kaup, F.-J., Drommer, W., Deegen E., and Schoon, H.-A. (1985): Licht- und elektronenmikroskopische Befunde bei Pferden mit chronisch obstruktiver Bronchitis. 9. Arb.-Tagg. d. Fachgr. Pfd.-Krh., DVG, Münster, 1985. 
Kissler, W. (1980): Surfactantüberproduktion - Eine Ursache von Makrophagenakkumulation in unbelüfteten Lungenbezirken. Verh. Dtsch. Pathol. Ges. 64, 215-218.

Klein, H.J. (1984): Der Histamininhalationsprovokationstest zur Bestimmung der unspezifischen Reagibilität der Atemwege beim Pferd. Hannover, Tierärztl. Hochsch., Diss.

McPherson, E.A., and Lawson, G.H.K. (1974): Some aspects of chronic pulmonary diseases of horses and methods of their investigation. Equine Vet. J. 6, 1-6.

Schoon, H.A., and Deegen, E. (1983): Zur Histologie der chronisch obstruktiven Bronchitis bei klinisch manifest erkrankten Pferden. Tierärztl. Prax. 11, 213-221.
Tscherniak, W. (1928): Curschmannsche Spiralen in den Lungen von Pferden. Berlin. Tierärztl. Wochenschr. 44, 399-403.

Dr. P. Costa

Klinik für Pferde, Tierärztliche Hochschule Hannover

Bischofsholer Damm 15

D-3000 Hannover 1, Germany 